\title{
Magnesium for Florida Turfgrasses ${ }^{1}$
}

\author{
T.W. Shaddox ${ }^{2}$
}

Soluble magnesium $(\mathrm{Mg})$ exists in soils primarily as $\mathrm{Mg}^{2+}$ (positively charged divalent cation) and is an essential element for all plants. Because $\mathrm{Mg}$ is often applied to turfgrasses in both granular and foliar forms, it is essential to understand the function of $\mathrm{Mg}$ in the plant, the dynamics of $\mathrm{Mg}$ in the soil, and the forms of $\mathrm{Mg}$ fertilizers. Additionally, it is also critical to be aware of the most current research regarding turfgrass responses to $\mathrm{Mg}$ in Florida so that you may make a more informed decision regarding $\mathrm{Mg}$ applications to turfgrass.

\section{Function of Magnesium in Turfgrasses}

The primary function of $\mathrm{Mg}$ in turfgrass is to serve as the central atom in the chlorophyll molecule. As much as $25 \%$ of plant Mg is used for this purpose (Carrow et al. 2001). Other functions of $\mathrm{Mg}$ in turfgrasses include enzyme activation, stabilization of ribosomes during protein synthesis, and maximization of energy during phosphate transfer (Havlin et al. 1999). Chlorophyll provides the green color in leaves, so a lack of $\mathrm{Mg}$ leads to a lack of green color ("chlorosis"), and turf can look pale and "hungry" for fertilizer even if other nutrients, such as nitrogen $(\mathrm{N})$ and phosphorus (P), are adequate. Magnesium is mobile within the plant; thus, deficiency symptoms typically appear as a chlorosis on older leaves first.

\section{Soil Magnesium}

The earth's crust is comprised of $1.93 \% \mathrm{Mg}$, but the majority of this $\mathrm{Mg}$ is bound in primary and secondary minerals and is not available for plant uptake (Havlin et al. 1999). Mehlich III extractable Mg in unfertilized Florida soils typically ranges from 20-40 parts per million (ppm) (Sartain 1993; Shaddox et al. 2016). Because it is positively charged, $\mathrm{Mg}$ can be retained on cation exchange capacity (CEC) sites on soil particles. However, the benefit of this retention may be quite low, because many Florida soils are predominantly sand and have a low CEC. In fact, Mg leaching does occur and may range from 5 to 60 lbs per acre per year (Havlin et al. 1999). In addition, the application of other cations, such as calcium $(\mathrm{Ca})$ in fertilizers or sodium $(\mathrm{Na})$ in reclaimed water, has a tendency to replace $\mathrm{Mg}$ on exchange sites, which can exacerbate $\mathrm{Mg}$ leaching and lead to $\mathrm{Mg}$ deficiency in turfgrasses.

The use of a soil test to manage $\mathrm{Mg}$ applications on Florida turfgrasses has limited value. Soil tests for agronomic crops utilize calibration response data to interpret the soil test value and provide the basis for a meaningful fertilizer recommendation. For Florida turfgrasses, Mg calibration responses have not been determined. A separate method of interpreting soil $\mathrm{Mg}$ levels is base saturation (the percentage of CEC possessed by basic cations). However, this soil testing philosophy has been determined to be inaccurate (Christians et al. 2006; St. John and Christians 2013) and should not be used in turf management. Therefore, $\mathrm{Mg}$ fertilizer recommendations based off a soil test are questionable (Kreuser 2015). However, a soil test can identify situations where Mg should not be applied. A Mehlich III $\mathrm{Mg}$ value $>20 \mathrm{ppm}$ indicates that a turfgrass response to Mg is unlikely (Sartain 1993). Mg applications are often not

1. This document is ENH1291, one of a series of the Environmental Horticulture Department, UF/IFAS Extension. Original publication date March 2018. Visit the EDIS website at http://edis.ifas.ufl.edu.

2. T. W. Shaddox, assistant professor, UF/IFAS Ft. Lauderdale Research and Education Center, Davie, FL 33314.

The Institute of Food and Agricultural Sciences (IFAS) is an Equal Opportunity Institution authorized to provide research, educational information and other services only to individuals and institutions that function with non-discrimination with respect to race, creed, color, religion, age, disability, sex, sexual orientation, marital status, national origin, political opinions or affiliations. For more information on obtaining other UF/IFAS Extension publications, contact your county's UF/IFAS Extension office. 
necessary because, under normal Florida conditions, many Florida soils already contain $>20 \mathrm{ppm} \mathrm{Mg}$.

\section{Forms of Magnesium Fertilizers Magnesium Sulfate}

Also known as Epsom salts, Mg sulfate has an analysis of $10 \% \mathrm{Mg}$, appears as a white, angular particle or prill, and is $100 \%$ water soluble. It is a common $\mathrm{Mg}$ fertilizer because it can be spread or sprayed and it is normally less expensive than other $\mathrm{Mg}$ fertilizers on a pound of Mg basis.

\section{Sulfate of Potash Magnesia}

Sulfate of potash magnesia (often referred to as SPM, or potassium magnesium sulfate) provides both potassium (K) and $\mathrm{Mg}$ in a single fertilizer. SPM can be more expensive than $\mathrm{Mg}$ sulfate per pound of $\mathrm{Mg}$ but, because it also contains $\mathrm{K}$, the cost of the fertilizer is offset because the applicator does not need to pay for additional K. SPM is manufactured in numerous forms, including brown prills and pink crystals, and the variety of particle sizes allows SPM to be applied to nearly any turfgrass, including putting greens, fairways, and home lawns. Typical analysis is $22 \% \mathrm{~K}$ and $10 \% \mathrm{Mg}$.

\section{Dolomite}

Dolomite is Ca-Mg carbonate and is usually used as a liming source rather than a $\mathrm{Mg}$ source. Dolomite analyses can vary, but a typical analysis is $18 \% \mathrm{Ca}$ and $10 \% \mathrm{Mg}$. The use of dolomite as a $\mathrm{Mg}$ source on soils with a $\mathrm{pH}>6.5$ is not recommended for turfgrass due to the associated increase in $\mathrm{pH}$. In contrast, turfgrass grown on low $\mathrm{pH}$ soils that are documented as $\mathrm{Mg}$-deficient may respond more favorably to dolomite than to calcium carbonate.

\section{Keiserite}

Keiserite $\left(\mathrm{MgSO}_{4} \cdot \mathrm{H}_{2} \mathrm{O}\right)$ is a naturally occurring mineral possessing $17 \% \mathrm{Mg}$ and is obtained during the mining of potash ore (Hardter et al. 2004). Few, if any, turfgrass fertilizers contain kieserite, but kieserite is included in some landscape fertilizers that may be inadvertently applied to home lawns. As with most minerals, kieserite must weather in order to release $\mathrm{Mg}$. To this end, kieserite has been documented to provide extended release of $\mathrm{Mg}$ compared to soluble Mg sources (Hardter et al. 2004). The influence of kieserite on Florida turfgrasses has not been investigated, and its value relative to other $\mathrm{Mg}$ sources is therefore unknown.

\section{Magnesium Oxide}

$\mathrm{Mg}$ oxide (MgO) contains $56 \% \mathrm{Mg}$ and is applied to Florida turfgrasses directly or in the form of frits (homogenous granules of metal oxides). Because $\mathrm{Mg}$ is in the oxide form, the solubility of $\mathrm{Mg}$ in $\mathrm{MgO}$ is extremely low. Studies have shown that $\mathrm{MgO}$ does not increase Mehlich III Mg levels in soils. However, when $\mathrm{MgO}$ is manufactured as a superfine particle, crop yields have increased relative to untreated soil (Hardter et al. 2004). Regardless, the Mg release rate is still too slow to meet plant nutrient demand (Hardter et al. 2004). All forms of $\mathrm{MgO}$ (hydroxides, frits, sucrates, etc.) should not be used to supply $\mathrm{Mg}$ to Florida turfgrasses.

\section{Magnesium Sucrate}

Magnesium sucrate is manufactured by pellitizing $\mathrm{MgO}$ powder into a black or dark-red granule. Although the granules rapidly disperse in water, this dispersion only forms a suspension of undissolved particles and, thus, $\mathrm{Mg}$ remains mostly insoluble. Mg sucrate has been studied on St. Augustinegrass in central and north Florida and does not increase turfgrass quality or color relative to untreated turfgrass.

\section{Magnesium Chelates}

Mg may be chelated for use on soils or as a foliar spray. Limited information exists on chelated Mg for turfgrasses; however, evidence indicates that chelated Mg may result in the same turf response and soil solubility as non-chelated $\mathrm{Mg}$ (Shaddox et al. 2016). Under normal Florida conditions, $\mathrm{Mg}$ will remain soluble in soils for as long as three weeks after application (Figure 1), which implies that the addition of a chelating agent is unnecessary.

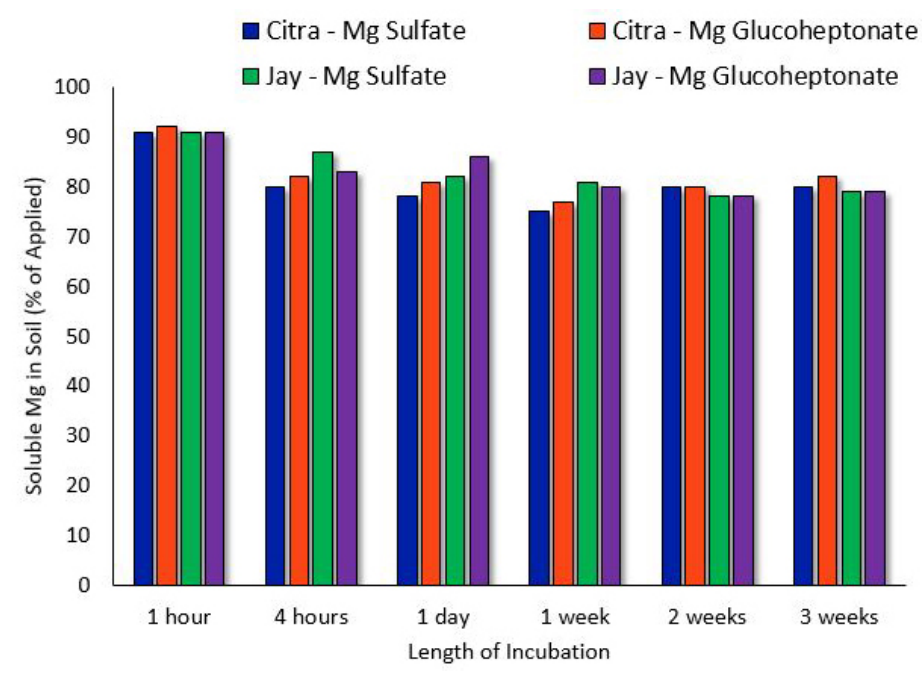

Figure 1. Solubility of Mg in both Jay and Citra soils. Within time levels, no differences were determined between chelated and non-chelated Mg (Shaddox et al. 2016). 


\section{Organic Magnesium}

Some natural organic fertilizers, such as municipal biosolids, may contain small amounts of $\mathrm{Mg}$. The value of this $\mathrm{Mg}$ in turfgrass management is difficult to determine because most organic $\mathrm{Mg}$ sources also contain nitrogen and/or phosphorus, which also increases turfgrass greening and can obscure the influence of Mg. Organic Mg may become plant available through mineralization and be taken up by the turfgrass. However, this dynamic has not been adequately investigated in Florida turfgrasses, and the value of using organic $\mathrm{Mg}$ remains unknown.

\section{Turfgrass Response to Magnesium}

A turfgrass response to $\mathrm{Mg}$ in Florida has been documented, but bona fide responses are uncommon. When a response occurs, the turfgrass usually appears darker green with little to no increase in growth. For two consecutive years in both central and north Florida, UF/IFAS researchers applied $\mathrm{Mg}$ in both granular and liquid forms to St. Augustinegrass. After eight applications of $20 \mathrm{lbs}$ of $\mathrm{Mg}$ per acre, no turfgrass response was observed in central Florida. However, in north Florida, a response was observed after the eighth application of foliar-applied Mg. These initial results indicate that the soil may provide adequate $\mathrm{Mg}$ to sustain acceptable turfgrass and the further addition of $\mathrm{Mg}$ via fertilizers may be of little value. When $\mathrm{Mg}$ is desired, current evidence indicates foliar Mg may be a more effective $\mathrm{Mg}$ source than granular.

\section{Summary}

Although a turfgrass response to $\mathrm{Mg}$ is rare, $\mathrm{Mg}$ is a common component of both granular and foliar nutrient programs for Florida turfgrasses. When Mehlich III soil test values are lower than $20 \mathrm{ppm} \mathrm{Mg}$, a $\mathrm{Mg}$ application may be warranted. Otherwise, $\mathrm{Mg}$ can be omitted from nutrient programs to reduce cost. If a Mg deficiency is confirmed, the use of foliar Mg may be more effective than granular.

\section{References}

Carrow, R.N., D.V. Waddington and P.E. Rieke. 2001. Turfgrass soil fertility and chemical problems: assessment and management. Chelsea, Michigan: Ann Arbor Press.

Christians, N., Y.K. Joo and J.H. Lee. 2006. "Interpreting soil tests for turfgrass." Korean Turfgrass Science 20: 223-235.
Hardter, R., M. Rex and K. Orlovius. 2004. "Effects of different $\mathrm{Mg}$ fertilizer sources on the magnesium availability in soils." Nutr. Cycl. Agroeco. 70: 249-259.

Havlin, J.L., J.D. Beaton, S.L. Tisdale and W.L. Nelson. 1999. Soil fertility and fertilizers: an introduction to nutrient management. 6th ed. Upper Saddle River, New Jersey: Prentice Hall.

Kreuser, W.C. 2015. "Simplifying soil test interpretations for turf professionals." Accessed March 3, 2017. http://turf.unl. edu/NebGuides/g2265.pdf

Sartain, J.B. 1993. "Interrelationships among turfgrasses, clipping recycling, thatch, and applied calcium, magnesium, and potassium." Agron. J. 85: 40-43.

Shaddox, T.W., J.B. Unruh, J.K. Kruse and N.G. Restuccia. 2016. "Solubility of iron, manganese, and magnesium sulfates and glucoheptonates in two alkaline soils." Soil Sci. Soc. Am. J. 80: 765-770. doi:10.2136/sssaj2015.10.0382.

St. John, R.A. and N.E. Christians. 2013. "Basic cation saturation ratio theory applied to sand-based putting greens." Int. Turf. Soc. Res. J. 12: 581-592. 